\title{
LEGAL ASPECT PROTECTION ON ONLINE SHOP OF THE THIRD PARTY (Study at CV. Mekar Jaya Persada-The Largest Online Shop in Demak www.Shopee.co.id)
}

\author{
Diyda Puji Lestari; \\ Kami Hartono. \\ Faculty of Law UNISSULA, Semarang \\ kami.h@unissula.ac.id
}

\begin{abstract}
Technological development nowadays is very fast is a communication technology, which presents a wide selection of forms of technology and sophistication. As a result of the very rapid technological developments such, gradually with its own information technology has changed the human life globally in terms of buying and selling online about how the law is not loaded or is described in the statute books of the civil law. So with the development of the sale require the creation of new legal rules. Online shop in Indonesia today has a lot of users ranging from social media to the online shop of mobile application software-based online shop. The method used is the juridical methods of sociology with emphasis on law is not only seen as regulations or rules, but also includes the operation of law in society, Research shows that buying and selling Legal Aspects Protection on Online Shop with third parties who do online marketplace of Shopee using an escrow service.
\end{abstract}

Keywords: Online Shop; Legal Protection; Third party.

\section{A. INTRODUCTION}

The dynamics of economic globalization which increasingly advanced today, pushing all countries in all over the world continue to run fast in reforming all of its economic policies ${ }^{1}$

At this time, the development of telecommunications and information more rapidly and increasing around the world each year. In the era of globalization the world is growing increasingly advanced, emerging technological sophistication of various types and features that enable people to work. Its presence will have great impact for human life from various aspects and dimensions of life. Technology is

1 I. Gusti Ayu Ketut Rachmi Handayani, Edi As'Adi, Guntur Hamzah, Tommy Leonard, Gunarto, Relationship between Energy Consumption in International Market and Indonesia Prices Regulation, International Journal of Energy Economics and Policy, 2017, 7(5), 9-15. hardware in the organizational structure that contains social value that allows individuals to collect, process, and exchange information. ${ }^{2}$

One of which is known as Internet Banking or E-Banking as one of the online payment system solutions that are very vulnerable to cybercrime. ${ }^{3}$

Technological developments such as electronic, radio, television, telephone, satellite continues to evolve. Technological development today is very fast is a communication technology, which presents a wide selection of forms of technology and sophistication. As a result of the very rapid

2 Zulkarimein, 1989, Communication Technology in Perspective Background \& Progress, Keni Media, Jakarta, p.15

3 Anis Mashdurohatun, Redyanto Sidji, Gunarto and Mahmutarom, Factors Causing Banking Cyber Crime in Indonesian, International Journal of Economic Research, Volume 14 Number 15 2017. P.293 
technological developments such, gradually with its own information technology has changed the global human life. The Internet is proof of the development of information and communication technologies, which have historically grown very rapidly and has created a new world or cyberspace. Cyberspace, a world of computer-based communication (computer mediated communication) this offers a new reality, namely virtual reality (virtual reality). ${ }^{4}$

With so over time, the Internet is growing from various aspects and dimensions of the value of life, especially social value. Internet changing social values in terms of communication to the environment, whether it is the immediate environment and the environment far. What was once the relationship is now quite often met with news send a message through the Internet that exist in the application whatsapp, facebook, instagram, telegram, etc. Even now the correspondence from the office or institutions in Indonesia simply by e-mail (electronic mail) only. All leverage the power of the technology according to their respective needs, the Internet also is like making someone it be up to date on something, so it requires a person to be online.

On line is a state-connected computer / network connected to the Internet. So when our computer online then able to access the internet / browsing searching for information on the internet. Online today not only through a computer, but also can be accessed through the HP (handphone) which has minimum network specifications GSM (Global System for Mobile communications) and CDMA (code

4 Mandy Meilarati, 2017, Legal Aspects of Internet-Based Fraud, Keni Media, Makasar, p.8 division multiple access). The easier it is connected between the regions without the need for much time.

It is certainly easier for businesses and consumers to continue to compete to get the best market, where the market is no longer as the convergence market between buyers and sellers, but the online market. Business operators increasingly creative and innovative, the competition is getting tight, do not go out to sell to the local market but also between the local via the internet which is now known by the online shop. The present society is no stranger to on-line shop.

online shop or shop online is a process of buying and selling goods or services over the Internet, goods or services in the offer the seller to the buyer in the form of images, photos, text, or video, with payment by bank transfer, send money online, COD (cash on delivery) etc. ${ }^{5}$ Shop online history itself actually originated from the delicatessen Pizza hut, they facilitate consumers with home delivery. A person can make a reservation via telephone calls and then escorted to the house or to the desired destination customers for testing in 1994 in Santa Cruz, California. At the end of 2000 many companies in Europe and America that facilitate services via the WWW (World Wide Web). Since then people began asosiate the term of e-commerce is the purchase of goods or services over the Internet. ${ }^{6}$

Then continue in 2009 see the website www.amazon.com experienced a rapid increase in yield of about 11 trillion by the time it becomes interesting other

5 Laudon, 2014, Doing Business Online Shop, Prasetio Grafika, Jakarta.p.23

6 Tim Berners, 2012, History of Online Store, Lee Media, Jakarta, p.35 
businesses. Site www.amazon.com which at first only online bookselling, 1995 continued to develop and sell various items. As the development of the time people are also increasingly interested in buying goods and services via e-commerce or online shop. Many competitors of State participating to divide shop run an online business, one of the largest online shop in Asia, namely www.Alibaba.com. Jack ma is the founder of the company, from all over the world share the gold suppliers joined in the company, company revenue reached 325 billion today.

In Indonesia many emerging companies developing online shop such as Lazada, Tokopedia, Bukalapak, OLX, Blibi, Shopee and so on. These companies are like in general selling online, just like somewhere. If a meeting place for buyers and sellers is the market, then the companies such as online shop the market place. The companies are just into a container or place an online shop without the sell and buy directly. Being an online market place shop from a variety of sellers and buyers, who participated in the membership certainly has its own policies and targeted marketing.

Such policies must be interrelated with the law, there is a policy of the company, there is also a legal policy that has been set in the legislation. In the policy of buying and selling a lot of agreement the parties must agree on these policies. Buysell agreement that was born on the second achievement of "agree" on the goods and prices. Once both parties have agreed on goods and prices, the new agreement was a valid sale. ${ }^{7}$

Buying and selling and stressed in a 1458 article that reads; "Buying and selling

7 Subekti, 2014, Various Agreements, Citra Aditya Bakti, Bandung, p.2 is considered to have occurred between the two sides immediately after they reached agreement on goods and prices, even though the goods had not been submitted and have not been paid".

As the times in the book of civil law in Indonesia BW, buying and selling online about how the law is not loaded or is described in the statute books of the civil law. So with the development of the sale require the creation of new legal rules. Online shop in Indonesia today has a lot of users ranging from social media to the online shop of mobile application softwarebased online shop. A wide variety of features and programs that many online shops offer one of which is Shopee. Although previously existing e-commerce or online shop comes first, for it Shopee now present in Indonesia as a supporting activity of shopping is easy and fast.

However, based on observations of the authors discovered a weakness in the application of the adverse Shopee between the seller and the buyer. That the absence of accountability Shopee against the seller and buyer who feel disadvantaged. Sellers feel disadvantaged by the program Free shipping (postage), disbursement of funds, cancellation of an arbitrary order by the consumer who is not responsible for and also the lack of a partnership contract between the seller with the Shopee. In addition, the consumer who felt disadvantaged by the system featured Free shipping programs is not clear when you check out the groceries. Based on the description of the background mentioned above, how Aspects of Legal Protection Online trading with third parties?

\section{B. DISCUSSION}

\section{Aspects of Legal Protection Online trading with third parties}


Sophisticated development of computer technology and telecommunication systems combined with the base, known also by the new popular thing called the Internet. Internet usage now it has grown around the world. In the context of a very complex internet fenomena is known as cyber space or as indefinitely. Use of the Internet evolved into an online shop. Online shop Buying and selling is the marketing, distribution, transaction, done via the internet, www, or television.

Such as the use of computer communication networks and internet use computers with a web browser to buy and sell products. Online shop or online store is a process of buying and selling goods or services over the Internet, goods or services in the offer the seller to the buyer in the form of images, photos, text, or video, with payment by bank transfer, send money online, COD (cash on delivery) and so on

Sell-buy (BW) is a turning agreement in which one party (the seller) promises to hand over ownership of the goods, while the other party (the purchaser) promises to pay the price of consisting of a sum of money in return from the acquisition of property rights. ${ }^{8}$ Words selling - buying shows that of the other parties named buyer. Shopee which is one of e-commerce which has an escrow service. Escrow is a legal agreement in which an item or object stored by a third party while waiting for the contents of the contract are fulfilled. The third party is usually called an escrow agent. In Indonesia there are various kinds of world trade factors that cause differentiation.
These factors include: ${ }^{9}$

1. Sellers and buyers are separated mainland.

2. Climate and weather.

3. Geografic layout.

4. Goods sent from one area to another sometimes must meet legal regulations issued each local government through checking the goods.

5. The use of language, dosing, scales, and different customs sometimes create misunderstandings that affect the value of the sale.

Shopee who was named Christ Feng Ceo coming from Singapore as well as its marketplace, all originally stood in Singapore. In conducting its business in Indonesia of course this involves a lot of legal rules that must be followed by the Shopee. The rule of law is not only involve one (1) legal, because in the world of trading is not a secret anymore if encountered a problem as any legal consequences. Therefore Indonesia as a developing country whose own past has its own self-sufficient economic policy with the aim of independently without the help of other countries today, is not self-sufficient must open itself capable considered able to resolve his legal problems.

On the basis of the Civil Code III book that embraces open systems into a place the parties in expressing his will. Then in the implementation on the principle of freedom of contract, contained in Article 1338 of the Civil Code includes restrictions are as follows: ${ }^{10}$
9 NinyasimeLislasih.com accessed on January 15, 2018, at $07.00 \mathrm{pm}$.

10 Johanes Gunawan, 1998, the Using Agreement and Its Implications On Access Standards Of Freedom Of 
1. Determining the will to close or not to close the agreement.

2. Choose which party will be in close agreement.

3. Determining the content of the agreement.

4. Assign a form of agreement.

5. Define how the closing of the agreement.

With the development of the current law remains Article 1338 of the Civil Code has become a guideline, for their buying and selling and other problems that exist because of the existence of an agreement and the agreement, even though there are laws governing the new law. Legal agreement itself there are many kinds, depending on what a thing or an object and how it is made in an agreement. ${ }^{11}$

Shopee who knew that Indonesia adheres to the civil law has set a requirement and services for $e-$ commerce in for him, terms and services are: ${ }^{12}$

1) Preliminary

This introduction is to introduce what services are made Shopee, so that the users are considered to know the service that has been given by Shopee.

Such services either be:

a) Site.

b) The services provided by the site and by Shopee client software available through the site.

c) All information, pages are linked, features, data, text, images, photographs, graphics, music,

Contract, Magazine Press Padjadjaran, Bandung, p.341

11 Subekti, 2001, The Law Covenant, Intermasa, Jakarta.p.11.

12 Shopee.co.id, Accessed on January 14, 2018, 17:30 $\mathrm{pm}$. sound, video, messages, tags, content, programming, software, application services (including by not limited to, any service of mobile applications) or other content available through the site or related services ( "content").

Services included between "buyers" and "sellers" are referred to as users. The actual sales contract is directly between the seller and buyer and Shopee not a party in it or any other contract between the buyer and the seller and is not responsible on the contract.

2) Privacy

To protect your rights better we have provided Shopee privacy policy to explain our privacy practices in detail and secret Shopee. By using the services or provide information on the site, you agree Shopee action to collect, use, disclose and / or approval process and your personal data as described in this privacy policy.

3) Limited license

Shopee provide limited license that can be revoked to users Shopee services to be subject to the terms and conditions Shopee.

4) Software

Shopee has been providing software as a part of the services subject to the terms and conditions of service Shopee.

5) Accounts and Security

Shopee account registration function with the user identification "User ID" and unique password, and provide certain personal information. If you choose a user ID that might be offensive or inappropriate by Shopee in its sole discretion, then Shopee reserves the right to suspend or 
terminate the accounts of users. If there is a third party who knows the user's privacy, the responsibility for any risk the responsibility of the user. Shopee is not responsible for any such third party who knows that user privacy is not an error Shopee. ${ }^{13}$

6) Terms of Use Shopee sites and services in force until terminated, as stipulated in the terms of this service or if it fails to comply with any term or condition of these terms \& Shopee services. Shopee can also perform termination with or without giving notice to the user.

7) Violation of the terms of Shopee's service

Violation of this policy may result in a range of actions, including, without limitation, any one of all matters bales below:

a) Elimination list

b) Restrictions imposed on account privileges

c) Suspension and termination end

d) Criminal charges

e) Civil action including by not limited to claims for damages and / or compensation temporarily or government compensation by the court.

8) Report violations of intellectual property rights

Users are individuals or independent businesses, and they do not have a relationship with Shopee in any way. Shopee not an agent or representative of users and does not hold and / or have the goods listed on the site, and if the user is the owner of intellectual property rights ("Own IPR") or an agent duly authorized legally by the

13 Interview by Director of PT Mekar Jaya Persada, on December 14, 2017, 17:00 pm owners of intellectual property rights ( "agent IPR" ) and users believe that the rights of users or rights authorizes a party who has been violated, to immediately inform us in writing via email to Shopee and include the following required documents to support claims of the user. ${ }^{14}$

9) Purchase and payment

Purchase and payment methods are supported by Shopee namely:

a) Credit card

b) Cash on delivery (COD)

c) Bank transfer

Shopee is not responsible and is not liable for any loss or damage to the buyer arising from the delivery of information and / or payment information entered by the buyer.

10) Warranty of Shopee

Shopee warranty is a service provided by Shopee or authorized agent to protect your purchase.

11) Shopee coin rewards system (loyalty points) "Shopee Coin" to purchase goods in other Shopee activities as may be prescribed from time to time.

12) Delivery

Shopee will inform sellers and buyers with details that can be checked and tracking of goods.

13) Cancellations, returns and money

Buyer may cancel an order prior to payment of the purchase money to the account of Shopee warranty.

14) The responsibility of the seller

Sellers must manage well and make sure to provide accurate information. Shopee not responsible if the seller does not provide clear information about the product being sold. With so Shopee also not responsible for what 
has been agreed between seller and buyer.

15) Cost

Shopee no charge to the user, only charge VAT and other applicable taxes.

16) Issues

If there are problems, "Shopee encourages users to communicate with each other in case problems arise in a transaction, because Shopee simply a platform where users trade. Buyers should be contacting them directly for any problems relating to goods purchased goods. Buy, users may be able to go to the local jurisdiction they claims court to resolve any problems that arise from the transaction. "

17) Criticism and suggestions

Shopee has been providing services to the user to be able to give criticism and advice. If the criticisms and suggestions were on show by both the buyer and the seller then directly indicated by the user. If the criticism and suggestions related to the system are made by Shopee, criticism and suggestions directly send it to Shopee.

18) Disclaimer

"The service is provided as is and without warranty, claim or statement made by Shopee of any kind either express, implied, or by, by not limited to, warranties of quality, performance, non-infringement, fitness, merchantability, or fitness for a particular purpose, and no guarantees are made for relationships, for implementation or usage of trade, by not limiting the provisions above and to the extent permitted by applicable law, Shopee not guarantee that the service, the site or the functions contained therein will be available, accessible, without disturbing, timely, secure, accurate, complete or error free, that defects, if any, will be corrected, or that this site and / or the server that enables the sites Shopee be available free of viruses, clock, timer, counter, worm, software lock, drop and devices, Trojan horses, routing, trap door, time bomb, or the performance of the site and or other material ".

19) Exclusions and limitations of liability "To the extent permitted by applicable law, under no circumstances Shopee will not be liable either in contract, warranty, tort (including, without limitation, negligence (whether active, passive or calculated), product liability, obligation tight or other theory), or any other cause of legal action, in fairness by legislation or other things."

20) Laws Governing

"Terms and service Shopee governed and construed in accordance with the laws of Singapore, without regard to conflict of legal principles. United nations convention on contracts for the international sale of goods and the law uniformity computer information transactions, to the extent applicable, is expressly disclaimed. Unless required otherwise by applicable law, any problems, controversy, claim or difference of any kind arising from or in connection with the terms and the service is on or associated with Shopee or one of the parties to be compensated based on the terms of this service will be referred and finally settled in arbitration in Singapore in accordance with the arbitration rules of the Singapore International arbitration Center ( "SIAC rules") applicable at the time, which rules are deemed incorporated by reference in this section. There will be one (1) arbitrator 
and arbitration using the English language. "

Terms and those services leads to a deal that's been made by Shopee, as follows: ${ }^{15}$

"By using the services Shopee or open an account, you provide acceptance and irrevocable consent to the terms of this agreement, including the terms and conditions and policies mentioned and / bound here."

"If you do not agree to these terms, please do not use our services or accessing the site. If you are under the age of 18 years or are minors according to the law to obtain approval of this agreement by law to obtain approval of this agreement under the applicable laws in your country ("adult according to the law"), you must obtain permission from a parent or guardian to open account parents and guardians must agree to the terms of this agreement. If you do not know whether you have asked for help parent or guardian. If you are parents or guardians of minors who created the account, you must accept the terms of this agreement on behalf of children under the age of these and you will be responsible for all use of your account or companies who use the account,

With the terms and services that have been created by Shopee, the authors assess that in making the terms and services many things beyond the responsibility Shopee, with the provision that it had already approved, if you want to be a user or section in Shopee.

The existence of such provisions, it is called a memorandum

15 Shopee.co.id, accessed on January 14, 2018, at 17:45 am. of understanding or often known by the MOU (memorandum of understanding). MOU basically not recognized in conventional law in Indonesia, better known as a precontract. In practice the MOU or precontract executed by the parties parties associated with the development of the law. So that companies also have practiced the MOU law practice. ${ }^{16}$

Basically $\mathrm{MOU}$ is a preliminary agreement, which regulates and provides, the opportunity for parties to test the feasibility of a more detailed and binding on future agreements. The MOU itself covers things - as follows: ${ }^{17}$

1) The MOU is the introduction of a tie (grounding certainty)

2) The contents of the MOU is - the main subject.

3) MOU has a temporary grace period.

4) MOU in the habit of not made a formal and there is no obligation that forced to contract or agreement made in detail.

5) If there are still doubts from one party to the other, the MOU was made to avoid difficulties in cancellation.

When making the MOU it still raises some doubt among those involved, it can be done by making an agreement.

According to the statute books of article 1313 of civil law, "a treaty is an act by which one or more persons bind himself to one or more persons." According to Article 1313 of the Civil Code, it can be understood that an

16 www.hukumonline.com, Accessed on January 15, 2018, at $09.00 \mathrm{am}$.

17 www.hukumonline.com, accessed on January 16, 2018, 13:00 pm. 
agreement containing the following elements:

1) Act

the act which is more to the legal acts or legal action, as done by the party under the agreement that will bring legal consequences for the parties to the pledge.

2) One or more of the one or more other people

Final agreement at least two people, entities, or legal institutions meet each other and deal with each other to give a statement to one another.

3) Bind themselves

In an agreement there is an element of "Promise" which means that there are legal consequences arising out of its own volition.

The existence of a definitive agreement also led to an agreement. In Article 1320 of the Civil Code For a legal contract terms required four conditions, namely: ${ }^{18}$

1) They agreed that bind himself.

2) Ability to create an engagement.

3) A certain thing

4) One reason kosher.

MOU has not spawned a legal relationship since the new MOU is an agreement in principle that is put in writing, creating a start become the basis for constructing in the relationship of law or agreement. In short MOU is just a preliminary agreement.

Shopee has made a proper agreement that the terms and services and the escrow agreement containing the arbitration agreement. Escrow agreement is a legal agreement, the agreement is made for increasing

18 Accessed through www.hukumonline.com at January $15,2018,11: 00 \mathrm{pm}$. interaction between society derived from the environmental system of different laws, especially after any major changes in the field of information technology, communications, and transportation.

Escrow is etymologically derived from the word in that France "escroue" which took the latin term "scroda" means "strip of parchment" and the term was adopted into the English legal terms to "escrow" which originally meant a roll of paper for writing the document (scroll). Then developed its use refers to a "deed" (deed). ${ }^{19}$

In the development of escrow is the principal transaction support, for example:

Sellers (A) and the buyer (B) has entered into sale and purchase clothes. Buyers (B) deems it necessary to ensure compliance with the completeness and correctness of the clothes or the specification to ensure compliance with the truth of the goods on behalf of the seller (A). Arises a doubt buyer (B) to the seller (A) will be certainty goods to be bought, then they have an agreement escrow (escrow agreement) with third parties who are impartial and do not have an interest in call Shopee (C), Shopee (C) this role is to receive, inspect and store transaction documents completeness of the goods, which must be fulfilled by the seller (A). Then reverse the Shopee $(C)$ will receive the purchase price to save money which must be submitted by the buyer (B). after all the requirements of any equipment or whether it's a document,

Position and function of this escrow is to support, supplement to a principal agreement (purchase
19 Rusli Pandika 2002, Escrow A Delivery Agreement, Pelita Harapan University Press, Jakarta, p.1 
agreement, licensing agreements, and so on. Therefore escrow held after the parties entered into an agreement to conduct a transaction. The main function of escrow is to protect the interest parties hold an agreement in principal to implement the agreement.

In Indonesia escrow established through an agreement, then the relationships that occur between the parties involved is a contractual relationship. On development in Indonesia escrow "SARA" is a selffinancing in the transaction. As Shopee has become the escrow agent by designating bank in Indonesia as the escrow holder (escrow holder). Escrow agent in escrow agreement to get the transfer transaction by reference to the designated bank as a transfer of power from the seller and the buyer to the escrow agent.

Delivery of power that are in agreement escrow basically has the elements of the surrender agreement power like in the article 1792 of the Civil Code, namely: "The authorization is an agreement with the person's name, gives power to another person, who received it, for and on its behalf conducting an affair. "which is the situation in Indonesia now is growing rapidly advanced technology and exchanging information in the trading world beyond the view of the law in Indonesia. The more the law also was created, one of which is the Act of the Republic of Indonesia Number 11 of 2008 and Government Regulation of 2012 on Information And Electronic Transactions, only be set on how electronic transactions only. ${ }^{20}$ In an online study author agreement not find the article which regulate the contract of sale online.

Because the article is deemed not in accordance with the conditions in Indonesia which now then re-embrace open systems according to Article 1338 Civil Code which says: "All the agreements made legally valid as law for those who make it.

All the agreements can't be withdrawn in addition to the agreement of both parties, or for reasons which by law is declared sufficient for it. An agreement must be in the state in good faith."

Based on these results requires a special and specific agreement on sale and purchase agreement online as additional agreements followed an agreement in principal with the law legal one another, so as to add to international trade with major implications for economic growth in Indonesia.

\section{CONCLUSION}

Legal aspects protection on online shop with third parties who do online marketplace Shopee using an escrow service. Escrow is an agreement which Shopee as having the authority to make an agreement between the seller and the buyer, as an online marketplace that provide escrow agreement. However the escrow agreement, whose name an agreement back to the book of civil law in Article 1338 BW namely: "all treaties made legally valid as law for those who make it. An agreement can't be retracted apart with both parties agreement, or for reasons which by law declared enough for that. "Which means that the same force of an agreement with the Act. 


\section{BIBLIOGRAPHY}

Anis Mashdurohatun, Redyanto Sidji, Gunarto and Mahmutarom, Factors Causing Banking Cyber Crime in Indonesian, International Journal of Economic Research, Volume 14 Number 152017.

Johanes Gunawan, 1998, the Using Agreement and Its Implications On Access Standards Of Freedom Of Contract, Magazine Press Padjadjaran, Bandung.

I. Gusti Ayu Ketut Rachmi Handayani, Edi As'Adi, Guntur Hamzah, Tommy Leonard, Gunarto, Relationship between Energy Consumption in International Market and Indonesia

Prices Regulation, International Journal of Energy Economics and Policy, 2017, 7(5). Laudon, 2014, Doing Business Online Shop, Prasetio Grafika, Jakarta. Mandy Meilarati, 2017, Legal Aspects of Internet-Based Fraud, Keni Media, Makasar. Rusli Pandika 2002, Escrow A Delivery Agreement, Pelita Harapan University Press, Jakarta. Zulkarimein, 1989, Communication Technology in Perspective Background \& Progress, Keni Media, Jakarta.

NinyasimeLislasih.com accessed on January 15,2018 , at 07.00 pm.

Subekti, 2001, The Law Covenant, Intermasa, Jakarta.

Subekti, 2014, Various Agreements, Citra Aditya Bakti, Bandung.

Tim Berners, 2012, History of Online Store, Lee Media, Jakarta.

Shopee.co.id, Accessed on January 14, 2018, 17:30 pm.

Shopee.co.id, accessed on January 14, 2018, at 17:45 am.

www. hukumonline.com, Accessed on January 15, 2018, at $09.00 \mathrm{am}$. www.hukumonline.com, accessed on January 16, 2018, 13:00 pm. 